\title{
Interaction of the mottler of white with transposable element alleles at the white locus in Drosophila melanogaster
}

\author{
James A. Birchler, ${ }^{1}$ John C. Hiebert, and Leonard Rabinow \\ Harvard University, Biological Laboratories, Cambridge, Massachusetts 02138 USA
}

\begin{abstract}
The mottler of white $(\mathrm{mw})$ locus has been determined to interact with alleles of the white $(\mathrm{w})$ eye color locus which are a subset of the transposable element insertion mutants. The transposable elements belong to six different types, including copia, and are located at several sites within the $w$ gene. Three $X$-ray-induced revertants of white-apricot $\left(w^{a}\right)$ no longer respond to $m w$, indicating that the transposable element must be present for $m w$ to act. The mottling property of the original allele was analyzed by combining the mw mutant with extra copies of $w^{a}$, either in a tandem duplication or in a transposable segment on chromosome two. Because neither duplication alters the mottling pattern, the event that results in the mottled pattern must occur at $m w$ and not at $w$. The pattern of a deficiency for the locus heterozygous with the original allele differs from that of $m w / m w$ females, confirming that this unique mottling property occurs at $\mathbf{m w}$. A new allele of $m w$ was induced in hybrid dysgenic crosses. It is not mottled, slightly enhances $w^{a}$ as a heterozygote, and further enhances as a homozygote or hemizygote. An analysis of RNA from $w^{a}$ with $m w$ shows a reduction of the fulllength normal RNA and a concomitant increase in certain RNAs that terminate within the copia element. These results suggest that several retrotransposon-induced alleles share an RNA processing function encoded by mw.
\end{abstract}

[Key Words: Drosophila; retrotransposons; white locus; RNA processing]

Received August 15, 1988; revised version accepted November 14, 1988.

The mottler of white $(\mathrm{mw})$ locus was first described by Muller in 1946. This mutant, near the center of the X chromosome, produces mosaic expression of the apricot allele of the white $(w)$ eye color locus, at the tip of the $\mathrm{X}$. The phenotype consists of nearly white sectors interspersed among those characteristic of apricot. In terms of sector size and distribution, the phenotype superficially resembles those that result from position effect variegation; yet, there is no response of the wild-type alleles of $w$, and cytological examination revealed no detectable chromosomal rearrangement. In many regards, $m w$ acts as a point mutation that mimics position effect variegation.

In an effort to characterize genes that exert a transacting regulatory effect upon the $w$ locus, a study of $m w$ was initiated. We find that this unusual mottling property is the result of a combination of phenomena. The loss of function at the $m w$ locus enhances a spectrum of transposon-induced mutants at $w$, caused primarily by retrotransposons, and the random inactivation of the original allele of $m w$ during development is responsible for the mosaic pattern of activity.
The enhancer function of $m w$ affects transposons located at various sites within the structural portion of $w$. In the case of the white-zeste mottled $\left(w^{2 m}\right)$ allele, the interaction with zeste $(z)$ must occur for the effect of $m w$ to be observed. The enhancement of white-apricot $\left(w^{a}\right)$ is additive with other modifying genes, such as suppressor of white-apricot $\left[s u\left(w^{a}\right)\right]$, and suppressor of forked [su(f)], which are effective on this allele. An analysis of the RNA profile from $w^{a}$ with and without $m w$ indicates that the enhancement involves a reduction in the level of normal-sized $w$ RNA with a corresponding increase in RNAs that terminate within copia. There is no effect on the level of total copia RNA. The $m w$ mutants identify a new RNA processing function utilized by transposon-induced alleles.

The mosaicism of the $w^{a} / m w$ interaction is due to a unique mottling property of the original $m w$ allele, rather than excision of copia or inactivation of the $w$ locus, as evidenced by the observation that a duplication of $w^{a}$ does not alter the mottling pattern and Southern blot analysis shows the retention of copia in $w$. The mottling allele heterozygous with a deficiency for the locus has a different pattern than homozygotes. A new allele induced on a wild-type chromosome is uniform for enhancement over the surface of the eye, in contrast to the original. These observations support the conclusion 
that the variegation is distinct from other types involving transposable elements (Fincham and Sastry 1974; Bryan et al. 1987).

\section{Results and discussion}

The first step in the characterization of $m w$ was to combine it with a series of mutants at $w$ that are hypomorphic to determine the array of responsive alleles. This collection includes representatives of structural gene lesions due to transposable element insertions, as well as those with undetectable lesions by the criterion of Southern gel analysis (Zachar and Bingham 1982). Also included are mutants in the 5 '-noncoding regulatory sequences. The rationale was that this series would be informative as to the interaction of the $m w$ and alleles at $w$ itself. To conduct this screen, an X chromosome was constructed that was carrying the following markers: $y$ $w$ ct $m w f$. This chromosome has the original $w$ mutant and therefore can be used to recover recombinants with various hypomorphic alleles between the $w$ and $c u t$ ( $c t$ ) loci. The $c t$ and forked $(f)$ loci flank the $m w$; therefore, recombinants that exhibit the eye color of the allele under test and the two markers represent the successful combination of the respective allele and the $m w \mathrm{mu}$ tant. The recombinant individual males were mated to attached $\mathrm{X}$ females, $C(1) D X$, y $w f / Y$, to establish a stock of each allele with the $m w$. The crossing scheme is illustrated in Figure 1. A further description of the mutants used can be found in Lindsley and Grell (1968).

The alleles affected by $m w$ are the following: apricot, apricot-4, buff, honey, spotted-55, and zeste-mottled. These six alleles are all insertion mutants at various locations within $w$. They represent six different families of transposons; however, five of these are retrotransposons. Table 1 lists the location of insertion and transposable element type for each of these alleles. Clearly, insertions at different sites can be affected, and mutants caused by several transposons will respond.

Although the affected alleles are all transposons, it is clear that not all insertion mutants at $w$ are affected. For example, crimson, blood, eosin, and six alleles resulting from IR hybrid dysgenesis are all unaffected. These represent insertions of a foldback $(\mathrm{FB})$ element $\left(w^{c}\right)$, blood

Figure 1. Genetic crosses to determine allele specificity at the $w$ locus. Males carrying the markers $y w c t m w f$ were mated to virgin females from the collection of $w$ allele stocks. The progeny were allowed to mate inter se, and the $F_{2}$ males were scored for single recombinants between the $w$ and $c t$ loci. Recombinant males were mated to attached females for confirmation and establishment of stocks. element, and I elements that belong to different classes of transposable elements than those in the affected alleles. On the other hand, white-spotted-1 is a B104 insertion in the $5^{\prime}$-noncoding region of $W$ and is not affected, whereas buff is a B104 insertion in the fourth intervening sequence and does interact.

The $m w$ has no effect with three revertants of $w^{a}$. One of these, $W^{a R 59 k 1}$, has been determined molecularly to contain only a single long terminal repeat (LTR) of copia (Carbonare and Gehring 1985). The fact that this revertant does not respond supports the conclusion that $\mathrm{mw}$ requires the presence of the complete transposable element to be effective on $w$ alleles.

\section{Genetic analysis of mottling properties}

The mottling property was characterized further. First it was of interest to determine whether this effect was due to a random inactivation of the $w$ locus in the early stages of development or whether there was a somatic excision or modification of the transposable element that generates a mosaic phenotype. In maize, snapdragon, and Drosophila simulans, transposable element systems can produce mosaic phenotypes due to the transposition of the element away from the locus (Fincham and Sastry 1974; Bryan et al. 1987). In general, these involve normal sectors on a mutant background that is fundamentally different from the phenotype generated by the combination of $w^{a}$ and $m w$, which has nearly null sectors on an intermediate background. Regardless of these considerations, a prediction is made that the phenotype of a duplication of $w^{a}$ would have a distinguishable phenotype in combination with $m w$ than the simplex alone. This is the case because both mechanisms (inactivation/modification) involve random events at a set point in development. If the null phenotype is caused by an event at the $w$ locus, a duplication of $w$ would have more tissue that exhibits the apricot level of pigment than the simplex form.

To test this, a tandem duplication of the $w$ region carrying two copies of the apricot allele (Green 1959a) was recombined onto the chromosome with the $c t m w f$ markers, as described above, for tests of allele specificity. The recombinants with a $D p(1: 1) w^{a}$ ct $m w f$ con-

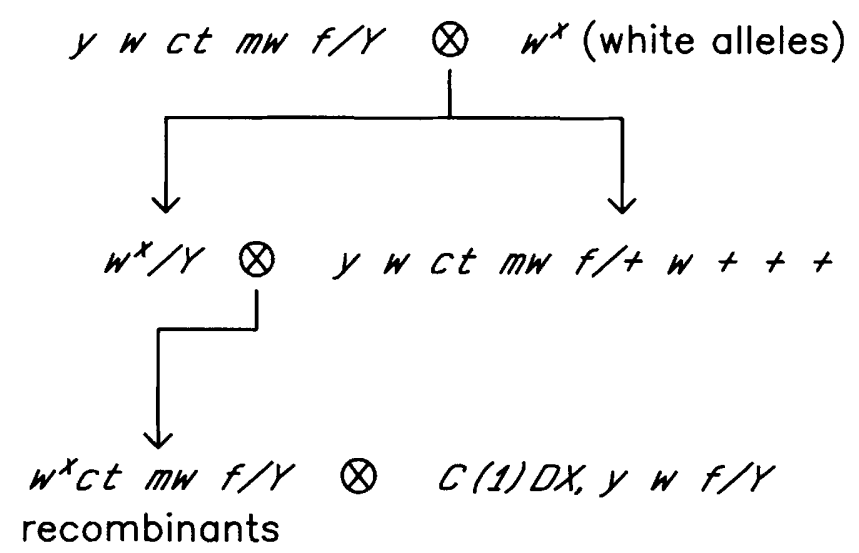


Table 1. Alleles of white tested with $\mathrm{mw}$

\begin{tabular}{|c|c|c|c|c|}
\hline Allele & $\begin{array}{l}\text { No. of } \\
\text { recombinants }\end{array}$ & Interaction & Lesion & Reference \\
\hline$w^{a}$ (apricot) & - & + & $\begin{array}{l}\text { copia insertion in second } \\
\text { intron }\end{array}$ & $\begin{array}{l}\text { Gehring and Paro (1980) } \\
\text { Bingham and Judd (1981) }\end{array}$ \\
\hline$w^{a 58112}$ (apricot revertant) & 3 & - & unknown & \\
\hline$w^{a 57111}$ (apricot revertant) & 2 & - & unknown & \\
\hline $\mathrm{W}^{a 59 \mathrm{k} 1}$ (apricot revertant) & 3 & - & $\begin{array}{l}\text { X-ray-induced revertant } \\
\text { solo copia LTR }\end{array}$ & $\begin{array}{l}\text { Carbonare and Gehring } \\
\text { (1985) }\end{array}$ \\
\hline$W^{a R M}$ (apricot revertant) & 5 & + & $\begin{array}{l}\text { transposable element } \\
\text { insertion in copia 5' LTR }\end{array}$ & Mount et al. (1988) \\
\hline$W^{a R 84 h}$ (apricot revertant) & 3 & + & $\begin{array}{l}\text { I element insertion in } \\
\text { copia } 3^{\prime} \text { LTR }\end{array}$ & Mount et al. (1988) \\
\hline$w^{2}$ (ivory) & 11 & - & $\begin{array}{l}\text { duplication of intron-1/ } \\
\text { exon2 sequences }\end{array}$ & $\begin{array}{l}\text { Karess and Rubin (1982) } \\
\text { Collins and Rubin (1982) } \\
\text { O'Hare et al. (1984) }\end{array}$ \\
\hline$w^{c}$ (crimson) & 3 & - & $\begin{array}{l}\text { FB transposable element } \\
\text { revertant of } w^{t}\end{array}$ & $\begin{array}{l}\text { Collins and Rubin (1982) } \\
\text { O'Hare et al. (1984) } \\
\text { O'Hare et al. (1983) }\end{array}$ \\
\hline$w^{s p}($ spotted $)$ & 16 & - & $\begin{array}{l}\text { B104 insertion in } 5^{\prime} \\
\text { regulatory region }\end{array}$ & $\begin{array}{l}\text { Zachar and Bingham (1982) } \\
\text { O'Hare et al. (1984) } \\
\text { O'Hare et al. (1983) }\end{array}$ \\
\hline$w^{s p 4}($ spotted-4) & 11 & - & $\begin{array}{l}\text { deficiency in } 5^{\prime} \text { cis } \\
\text { regulatory region }\end{array}$ & $\begin{array}{l}\text { Zachar and Bingham (1982) } \\
\text { O'Hare et al. (1984) }\end{array}$ \\
\hline$w^{s p 2}($ spotted-2) & 4 & - & $\begin{array}{l}\text { deficiency in } 5^{\prime} \text { cis } \\
\text { regulatory region }\end{array}$ & Zachar and Bingham (1982) \\
\hline$w^{s p 81 d 5}$ (spotted-81d5) & 4 & - & $\begin{array}{l}\text { deficiency in } 5^{\prime} \text { cis } \\
\text { regulatory region }\end{array}$ & Davison et al. (1985) \\
\hline$w^{s p 55}$ (spotted-55) & 10 & + & retrotransposon insertion & $\begin{array}{l}\text { Zachar and Bingham (1982) } \\
\text { O'Hare et al. (1984) }\end{array}$ \\
\hline$w^{b f 2}$ (buff- -2$)$ & 7 & - & unknown & \\
\hline$w^{t}($ tinged $)$ & 4 & - & unknown & \\
\hline$w^{c o}$ (coral) & 6 & - & unknown & \\
\hline wec3 $\{$ ecru-3| & 5 & - & unknown & \\
\hline$w^{\text {mo }}$ (mottled-orange) & 2 & - & unknown & \\
\hline$w^{c t}$ (coffee) & 2 & - & point & Zachar and Bingham (1982) \\
\hline$w^{a 3}$ (apricot-3) & 11 & - & point & Zachar and Bingham (1982) \\
\hline$w^{a 2}$ (apricot-2) & 11 & - & point & Zachar and Bingham (1982) \\
\hline$w^{\text {sat }}$ (satsuma) & 6 & - & point & Zachar and Bingham (1982) \\
\hline$w^{c o l}$ (colored) & 6 & - & point & Zachar and Bingham (1982) \\
\hline$w^{B w x}$ (Brownex) & 8 & - & point & Zachar and Bingham (1982) \\
\hline$w^{b l}$ (blood) & 4 & - & $\begin{array}{l}\text { retrotransposon insertion } \\
\text { in intron } 2\end{array}$ & $\begin{array}{l}\text { Zachar and Bingham (1982) } \\
\text { Bingham and Chapman } \\
\text { (1986) }\end{array}$ \\
\hline$w^{b f}$ (buff) & 5 & + & $\begin{array}{l}\text { B104 transposable element } \\
\text { insertion in intron } 4\end{array}$ & $\begin{array}{l}\text { Zachar and Bingham (1982) } \\
\text { O'Hare et al. (1984) } \\
\text { O'Hare et al. (1983) }\end{array}$ \\
\hline$w^{a 4}$ (apricot-4) & 6 & + & $\mathrm{BEL}$ insertion into intron 2 & $\begin{array}{l}\text { Zachar and Bingham (1982) } \\
\text { Goldberg et al. (1983) }\end{array}$ \\
\hline$w^{e}($ eosin) & 4 & - & $\begin{array}{l}\text { transposable element } \\
\text { reversion of } w^{1} \text { (Doc } \\
\text { element) }\end{array}$ & $\begin{array}{l}\text { Zachar and Bingham (1982) } \\
\text { O'Hare et al. (1984) } \\
\text { Hazelrigg (1987) }\end{array}$ \\
\hline$w^{2}($ eosin-2) & 2 & - & $\begin{array}{l}\text { derivative of } w^{1} \text { (Doc } \\
\text { element) }\end{array}$ & O'Hare et al. (1984) \\
\hline$w^{\text {ch }}$ (cherry) & 8 & - & $\begin{array}{l}\text { reversion of } w^{1} \text { (Doc } \\
\text { element) }\end{array}$ & $\begin{array}{l}\text { Zachar and Bingham (1982) } \\
\text { O'Hare et al. (1984) }\end{array}$ \\
\hline$w^{h}$ (honey) & 7 & + & $\begin{array}{l}\text { deletion reversion of } w^{1} \\
\text { (Doc element })\end{array}$ & $\begin{array}{l}\text { Zachar and Bingham (1982) } \\
\text { O'Hare et al. (1984) }\end{array}$ \\
\hline$w^{\text {apl }}$ (apricot-like) & 2 & - & $\begin{array}{l}\text { P-M hybrid dysgenic } \\
\text { revertant of } w^{1} \text { (Doc } \\
\text { element) }\end{array}$ & C. McElwain (pers. comm.) \\
\hline$w^{I R 1}$ & 4 & - & I element insertion & Sang et al. (1984) \\
\hline
\end{tabular}


Table 1. Continued

\begin{tabular}{|c|c|c|c|c|}
\hline Allele & $\begin{array}{l}\text { No. of } \\
\text { recombinants }\end{array}$ & Interaction & Lesion & Reference \\
\hline$W^{I R 2}$ & 2 & - & $\begin{array}{l}\text { I element insertion } \\
\text { revertant of } w^{1} \text { (Doc } \\
\text { element) }\end{array}$ & Sang et al. (1984) \\
\hline$W^{I R 3}$ & 5 & - & I element insertion & Sang et al. (1984) \\
\hline$w^{I R 4}$ & 4 & - & I element insertion & Sang et al. (1984) \\
\hline$w^{I R 5}$ & 4 & - & I element insertion & Sang et al. (1984) \\
\hline$w^{I R \sigma}$ & 4 & - & I element insertion & Sang et al. (1984) \\
\hline$z w^{i s}$ (isoxanthopterinless) & 12 & - & unknown & \\
\hline$W^{z m}$ (zeste-mottled) & 11 & - & $\begin{array}{l}3 \mathrm{~S} 18 \text { transposable element } \\
\text { insertion in intron } 1\end{array}$ & $\begin{array}{l}\text { Zachar and Bingham (1982) } \\
\text { O'Hare et al. (1984) }\end{array}$ \\
\hline$z w^{z 1}$ (zeste-light) & 4 & - & derivative of $w^{z m}$ & Judd (1963) \\
\hline$z w^{z m}$ (zeste-mottled) & 6 & + & $\begin{array}{l}3 S 18 \text { transposable element } \\
\text { insertion in intron } 1\end{array}$ & $\begin{array}{l}\text { Zachar and Bingham (1982) } \\
\text { O'Hare et al. (1984) }\end{array}$ \\
\hline$z w^{a}$ & 3 & + & copia insertion in intron 2 & $\begin{array}{l}\text { Gehring and Paro (1980) } \\
\text { Bingham and Judd (1981) }\end{array}$ \\
\hline$z^{a} w^{a}$ & 1 & + & copia insertion in intron 2 & $\begin{array}{l}\text { Gehring and Paro (1980) } \\
\text { Bingham and Judd (1981) }\end{array}$ \\
\hline$z D p(1 ; 1) w^{+61 e 19}$ & 5 & - & duplication of white locus & \\
\hline
\end{tabular}

The allele designations are given for each mutant recombined onto the $y w$ ct $m w$ f chromosome, as well as the number of recombinants replacing $w$. The third column notes whether the respective $w$ allele was affected by $m w$. For each genotype, the status of the knowledge of its molecular lesion is given along with the appropriate reference.

stitution were mated to compound $\mathrm{X}$ females to produce stocks. When these males are compared to $w^{a} c t m w f$, the pattern of pigment is the same; however, the intensity of pigmented regions is greater than with only a single copy of apricot present.

The second experiment was to cross the $m w$ stock with one carrying a transposed copy of $w^{a}$ in a Transposable Element, (Ising 1964) located on the second chromosome. For this, males of the constitution $\operatorname{In}(1) w^{-}$ $\mathrm{rst}^{-}$, y $\mathrm{wrst} / \mathrm{y}^{+} Y_{;} ; \operatorname{In}(2 L) C y \operatorname{In}(2 R) C y, C y d p T E 1\left(w^{a}\right)$ $\mathrm{cn}^{2} /+$ were crossed to $y^{2} w^{a} c t m w f$ females. Among the $\mathrm{F}_{1}$ males are those that are $C y$ and carry an extra copy of $w^{a}$ within the second chromosome balancer and those that have normal wings and only the $w^{a}$ present on the $\mathrm{X}$. Both of these types of males were identical in the pattern of mosaicism. Again, the duplicated males differed only in that the intensity of color in the pigmented areas was greater. All copies of $w^{a}$ present in these cases become enhanced in the same developmental lineage. These results suggest that the random mottling property is a characteristic of the original allele of $m w$ and not of the $w$ locus. The properties of a newly induced allele of $m w$, described below, are consistent with this view because it does not exhibit a mottled phenotype.

A sex difference exists in the mottling pattern. In general, females have portions of the pigmented areas that are lighter than normal $w^{a}$ compared with males. However, when females are produced that have a deficiency opposite the $m w$ allele (see below), the pattern resembles that of the male. This result is interpreted such that the two copies of $m w$ in a normal female become inactive in different cell lineages. Because $m w$ has a detectable dominant effect, the random inactivation of the two copies versus one would produce this difference.

To test whether enhancers of position effect variega- tion could modify the pattern of mottling, males carrying five different dominant enhancers of variegation (Gsell 1971; Spofford 1976), heterozygous with $\operatorname{In}(2 L) C y$ In(2R)Cy on chromosome two or $C x D$ on chromosome three, were crossed to females homozygous for $w^{a R 84 h} c t$ $m w f$. The male progeny were scored for any difference between the enhancer chromosome and the balancer. None of the tested enhancers, $E($ var $) 5, E($ var $) 7, E($ var $) 8$, or $E$ (var) 12 on the second chromosome or $E$ (var) 13 on the third chromosome, produced any discernible effect on the mottling pattern. Thus, by this criterion, as well as previous ones (Oster 1957, and those noted in the introduction), the mottling is a distinct phenomenon from position effect variegation, despite the gross similarity.

\section{Localization of $\mathrm{mw}$}

To localize $m w$ cytogenetically, two types of aberrations were used. First insertional translocations of portions of the $\mathrm{X}$ chromosome into autosomal sites were crossed to a $y^{2} w^{a} c t m w f$ stock to test for the complementation of $m w$ by the translocated segment. The aberrations used were $D p(1 ; 2) V^{+75 d}, D p(1 ; 2) V^{+63 i}$, $D p(1 ; 2) v^{+65 b}$, and $D p(1 ; 3) s n^{13 a 1}$. Males heterozygous for the duplications were crossed to females of the aforementioned $m w$ stock. The $F_{1}$ males were screened for normal $w^{a}$ phenotype, which should be present in approximately half of the male progeny if the transposition carries the normal allele of $m w$. In each case, several hundred progeny were scored. Only $D p(1 ; 2) v^{+75 d}$ complemented the mottled phenotype in the male progeny.

Second, $\mathrm{X}$ chromosome deficiencies, $\mathbf{v}^{115}, \mathrm{~N} 110$, $\mathrm{N} 105$, and C52 were crossed to males from a $w^{a}$ stock. The heterozygous females were backcrossed to males of $y^{2} w^{a}$ ct $m w f$ constitution. If $w^{a}$ is recombined to the 
deficiency chromosome and it is missing the normal allele of $m w$, then a fraction of the female progeny would exhibit mottling. Deficiency C52 uncovered $\mathrm{mw}$. A stock was established of the $w^{a}$ deficiency chromosome by balancing it with FM6. Collectively, the duplication and deficiency data place $m w$ between $9 \mathrm{~A} 2$ and $9 \mathrm{~B} 1$ on the cytological map. These data are summarized in Table 2.

\section{New allele induction}

A new allele of $m w$ was sought to understand the action of the original one. One possibility is that the $\mathrm{mw}$ might be a modified transposable element that encodes a trans-acting factor that is effective upon the elements present in the responsive $w$ alleles. A system of this type occurs with human T-cell leukemia virus type 1 (HTLV1 1) in which a regulator is encoded in viral sequences (Fuiisawa et al. 1985). If such were the case, one would expect that new alleles could not be generated from a normal chromosome at the same genetic location. If, on the other hand, the locus is one normally present in the Drosophila genome, which is in some manner involved in the expression of transposon-induced mutants at $w$, a new allele could be produced.

For the mutant screen, Harwich $\mathrm{P}$ strain males were crossed to $w^{a} M$ strain females (see Fig. 2). This cross produces progeny that are active in the P-M system of hybrid dysgenesis, thus acting as a mutagen by mobilizing the $P$ elements in the germ line of the $F_{1}$ (Rubin et al. 1982). The hybrid males are $w^{a}$ and dysgenic. They were backcrossed to $y^{2} W^{a} c t m w f$ females. If a mutation were induced in the dysgenic males, an exceptional + $w^{a}+m w+$ female would be found among those that are otherwise exclusively $w^{a}$. The screen was performed in this way in the event that newly generated alleles might be recessive lethals. In such case, they could be recognized by their phenotype in the heterozygote and yet recovered.

From a progeny of $\sim 5000$ flies, one exceptional female was found that had $w^{a}$ mottled eyes and was wild type for the markers $y, c t$, and $f$. This female was crossed with males from the $w^{a}$ stock. Among the progeny were

Table 2. Cytological localization of $\mathrm{mw}$

\begin{tabular}{llc}
\hline Aberrations & Cytology & $m w^{+a}$ \\
\hline$D p(1 ; 2) v^{+63 i}$ & $9 \mathrm{~F} 6-7-10 \mathrm{~A} 6-7$ & - \\
$D p(1 ; 2) v^{+65 b}$ & $10 \mathrm{~A} 1-11 \mathrm{~A} 7$ & - \\
$D p(1 ; 3) s n^{13 a 1}$ & $6 \mathrm{C} 11-7 \mathrm{C} 9$ & - \\
$D p(1 ; 2) v^{+75 d}$ & $9 \mathrm{~A} 2-10 \mathrm{C} 2$ & + \\
$D f(1) v^{L 15}$ & $9 \mathrm{~B} 1-10 \mathrm{~A} 1$ & + \\
$D f(1) N 110$ & $9 \mathrm{~B} 3-4-9 \mathrm{D} 1-2$ & + \\
$D f(1) N 105$ & $10 \mathrm{~F} 7-8-11 \mathrm{C} 4-\mathrm{D} 1$ & + \\
$D f(1) C 52$ & $8 \mathrm{EF}-9 \mathrm{CD}$ & - \\
\hline
\end{tabular}

Cytological determinations are by G. Lefevre, as provided by the Caltech Drosophila stock center.

a Designations indicate the presence $(+)$ or absence $(-)$ of $m w^{+}$ in the respective aberrant chromosome.

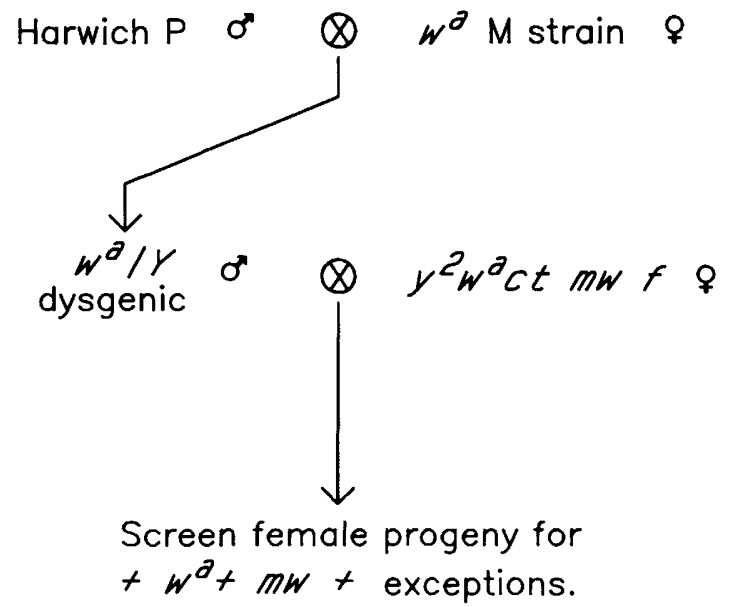

Figure 2. Induction of a new allele of $m w$ by P-M hybrid dysgenesis. Harwich $P$ strain males were mated to $W^{a}$ virgin $M$ strain females. The $F_{1} w^{a}$ males were crossed to females carrying the multiply marked $\mathrm{X}$ chromosome with the original $m w$ mutant, $y^{2} w^{a}$ ct $m w f$. The subsequent female progeny was screened for $+w^{a}+m w+$ exceptions among the $+w^{a}+++$ normal females.

$w^{a} m w$ females and two major classes of males. These were $y^{2} w^{a} c t m w f$ and an enhanced $w^{a}$ class. The latter represents the new allele. In contrast to the original, it is not mottled. Also, although there was no selection against lethality in the screen, the mutant is viable. The new allele has been designated $m w^{2}$.

When the new allele is backcrossed to $w^{a}$ females, the resulting progeny have females with lighter eyes than males. Thus the mutant exerts a partially dominant effect.

The new allele was backcrossed to an attached $\mathrm{X}$ $C(1) D X, y w f / Y$ from an $M$ strain. Because there are $\mathrm{P}$ elements still present in the mutant stock, this cross was dysgenic. If the mutant is due to the insertion of a $P$ element, the mutant will revert to normal. The progeny were allowed to mate inter se and the $F_{2}$ males scored for reversions. From a total of 361 males screened, 6 were recovered that returned to the apricot phenotype. These were individually mated to $C(1) D X$, y $w f / Y$ females to establish stocks.

To test the allele specificity of the new allele, it was recombined with $\mathrm{X}$ markers to produce a $w^{B w x} c t m w^{2} f$ chromosome. Because $w^{B w x}$ has a unique phenotype and is dominant, it was chosen to test the specificity of $m w^{2}$. In an analogous scheme used for $m w$, each allele replaced $w^{B w x}$ on an otherwise $c t m w^{2} f$ chromosome, and these recombinants were crossed to $C(1) D X$, y $w f / Y$ virgin females to establish stocks. The results are shown in Table 3. The specificity of the new allele is identical to the original; however, in no case is the effect mottled.

The new allele was presumed to be a P-element insertion because it arose during hybrid dysgenesis and is readily reverted by the same. It was localized by in situ hybridization of a biotin-labeled P-element probe. Salivary gland squashes of the mutant males and of revertant 3 were prepared and probed with the $P$ element 
Table 3. Alleles of white tested with $\mathrm{mw}^{2}$

\begin{tabular}{|c|c|c|}
\hline & $\begin{array}{l}\text { No. of } \\
\text { recombinants }\end{array}$ & Interaction \\
\hline$w^{a}$ (apricot) & - & + \\
\hline$w^{a 58112}$ (apricot revertant) & 5 & - \\
\hline$w^{a 57 i 11}$ (apricot revertant) & 2 & - \\
\hline$w^{a 59 k I}$ (apricot revertant) & 5 & - \\
\hline$w^{a R M}$ (apricot revertant) & 9 & + \\
\hline$w^{a R 8 a h}$ (apricot revertant) & 3 & + \\
\hline$w^{i}$ (ivory) & 3 & - \\
\hline$w^{c}$ (crimson) & 5 & - \\
\hline$w^{s p}$ (spotted) & 2 & - \\
\hline$w^{s p 4}$ (spotted-4) & 1 & - \\
\hline$w^{s p 2}$ (spotted-2! & 3 & - \\
\hline$w^{s p 81 d 5}$ (spotted-81d5) & 5 & - \\
\hline wsp5s $_{\text {(spotted-55) }}$ & 2 & + \\
\hline$w^{b f 2}$ (buff-2) & 3 & - \\
\hline$w^{t}$ (tinged) & 2 & - \\
\hline$w^{c o}$ (coral) & 2 & - \\
\hline$w^{e c 3}$ (ecru-3) & 3 & - \\
\hline$w^{m o}$ (mottled-orange) & 1 & - \\
\hline wef (coffee) & l & - \\
\hline$w^{a 3}$ (apricot-3) & 7 & - \\
\hline$w^{a 2}$ (apricot-2) & 5 & - \\
\hline$w^{\text {sat }}$ (satsuma) & 2 & - \\
\hline$w^{c o l}$ (colored) & 3 & - \\
\hline$w^{b f}$ (buff) & 2 & - \\
\hline$w^{B w x}$ (Brownex) & 3 & - \\
\hline$w^{b l}$ (blood) & 3 & - \\
\hline$w^{a 4}$ (apricot-4) & 4 & + \\
\hline$w^{e}(\operatorname{eosin})$ & 1 & - \\
\hline$w^{22}($ eosin- -2$)$ & 1 & - \\
\hline$w^{h}$ (honey) & 1 & + \\
\hline$w^{a p l}$ (apricot-like) & 6 & - \\
\hline$W^{I R 1}$ & 3 & - \\
\hline$W^{I R 2}$ & 3 & - \\
\hline$W^{I R 3}$ & 3 & - \\
\hline$w^{I R 4}$ & 3 & - \\
\hline$W^{\prime R 5}$ & 3 & - \\
\hline$w^{l R \sigma}$ & 3 & - \\
\hline$z^{a} w^{2 m}$ (zeste-mottled) & 2 & + \\
\hline$z w^{2 m}$ (zeste-mottled) & 10 & + \\
\hline$w^{2 m}$ (zeste-mottled) & 9 & - \\
\hline$z^{a} w^{2}$ (zeste-light) & 2 & - \\
\hline$z w^{2 l}$ (zeste-light) & 3 & - \\
\hline$w^{2 l}$ (zeste-light) & 3 & - \\
\hline$z^{a} w^{i s}$ (isoxanthopterinless) & 5 & - \\
\hline$z w^{\text {is }}$ (isoxanthopterinless) & 3 & - \\
\hline$w^{i s}$ (isoxanthopterinless) & 2 & - \\
\hline
\end{tabular}

Table 1 describes the molecular lesion of each allele.

XP-19 (a gift from D. Rio), a complete element without flanking sequences. The results of this analysis place the gene in $9 \mathrm{~A}$ (see Fig. 3).

The $m w^{2}$ allele was used to test further that the difference in pattern between males and females does not involve the dosage of the $w$ locus. Heterozygotes at $w$ for two responding alleles that are phenotypically distinguishable in a background of $m w$ were constructed. The rationale is that if the two $w$ alleles are enhanced simultaneously, the mottling pattern would show only the
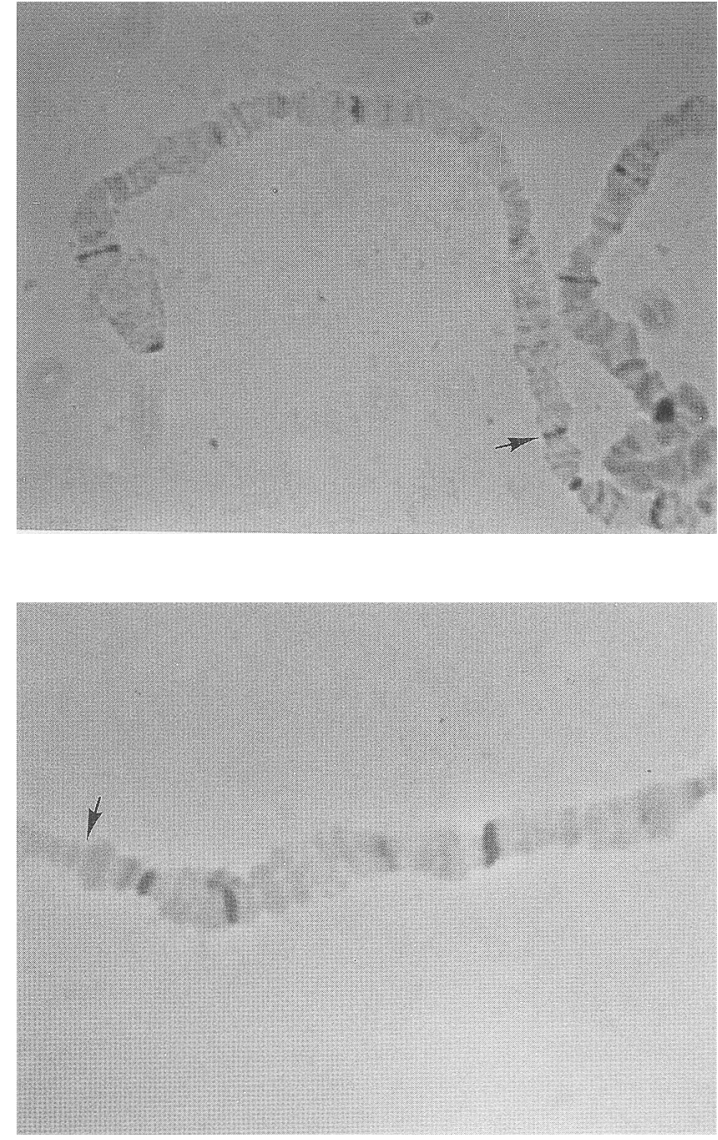

Figure 3. In situ hybridization of $\mathrm{P}$ element sequences to a hybrid dysgenically induced mutant of $m w$ and a revertant. (Top) Portion of the $\mathrm{X}$ chromosome showing hybridization in section 9A from the $m w^{2}$ mutant; (bottom) portion of the $\mathrm{X}$ chromosome showing loss of hybridization in the revertant strain.

heterozygous color interspersed with lighter sectors. If, on the other hand, the two alleles are independent, the pattern would be a mixture of the two types. For this cross, males of genotype $y^{2} s c w^{a R M}$ ct $m w f / Y$ were mated to $y^{2} w^{a}$ ct $m w^{2} f$ virgin females. The $F_{1}$ females are heterozygous at $w$ for the apricot allele and the much darker revertant of apricot, $w^{a R M}$. At $m w$, they are heterozygous for the original $m w$ allele and the newly induced nonmottling one, $m w^{2}$. If the two $w$ alleles were affected randomly, there should be a pattern of revertant, apricot, and enhanced sectors. If not, the pattern would resemble the revertant and $m w$ combination alone. The latter result was found, suggesting that both alleles at $w$ are enhanced in the same cell lineages. The pattern resembles that found in Df(1)C $52 / \mathrm{mw}$ females and in males, but all of the pigmented areas were of a $w^{a} / w^{a R M}$ type, rather than an interspersion of the two.

The new allele was used to test whether excision of the copia element is responsible for the altered phenotype of $w^{a} m w$ despite the facts that the phenotype is fundamentally different from other systems in which mosaic patterns result from transposable element insertion and that the mode of retrotransposon transposition 
and excision also differs. In such systems, mutant tissue is interspersed with normal (or nearly so) tissue. In this case, a leaky phenotype is altered to a nearly null type. It is conceivable, however, that excision would routinely be such that the $w$ locus would not be restored to a functional state. For this to be the case, it could occur only in the soma, as no germ line change of $w^{a}$ to $w$ has been observed with $m w$ or $m w^{2}$. To test this, DNA from $w^{a}$, $w^{a} m w^{2}$, and Canton $S$ wild type was prepared and digested with the restriction endonucleases SalI and $\mathrm{XbaI}$. Sites for these enzymes flank the $w$ locus region in which the copia transposon is inserted and $\mathrm{XbaI}$ cuts once within the element. The digested DNAs were subjected to electrophoresis, transferred to nylon membrane, and probed with a labeled subclone of $w$ extending from the SalI to $\mathrm{XbaI}$ sites mentioned above. Because $m w^{2}$ produces an enhancement of $w^{a}$ in all adult tissues in which $w$ is expressed, any alteration in the size of the restriction fragments due to excision or rearrangement of copia should be detectable. The $w^{a}+$ class serves as a control for the size of the two fragments with copia present and Canton S for the size of the fragment in the absence of copia. The results of this analysis indicate that $w^{a}+$ and $w^{a} m w^{2}$ are indistinguishable (Fig. 4). Even after longer exposures, the $w^{a} m w^{2}$ lane shows no additional fragments. It should be noted that these experiments could not detect the deletion of all sequences related to the probe. However, this possibility is unlikely, considering that the $w^{a}$ enhanced phenotype is not completely bleach white, which is characteristic of $w$ deficiencies. Thus, there is no evidence on the DNA level for alteration of copia sequences in accordance with the genetic evidence.

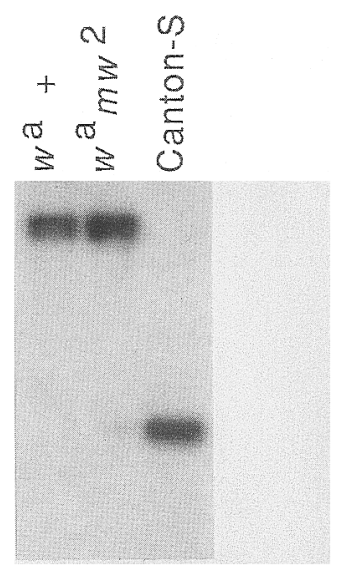

Figure 4. Southern analysis of $w^{a}+, w^{a} m w^{2}$, and Canton S. DNA was prepared from the three genotypes, digested with $X b a I$ and Sall, separated in $1 \%$ agarose, transferred to nylon membrane, and probed with an oligolabeled DNA XbaI-SalI fragment. No difference was detected between $w^{a}+$ and $w^{a}$ $m w^{2}$ even after long exposures.

\section{Interaction with $\mathrm{z}$}

$m w$ is effective on the $w^{2 m}$ allele only when $z$ is present. The $w^{2 m}$ allele is a $3 S 18$ insertion within the first intron of $w\left(O^{\prime}\right.$ Hare et al. 1984). It responds to $z$ in a mosaic fashion in males (Becker 1960), in contrast to most other affected $w$ alleles that require two copies to respond. The pattern of $y^{2} z w^{2 m} c t m w f$ males is such that within the sectors that have reduced pigment due to $z$ there is additional mottling that lightens the eye color even further. When a $y^{2} z w^{2 m} c t m w^{2} f$ chromosome is made, the pattern is the same as with $z w^{z m}$, but the intensity of the pigment in the lighter regions of the eye is reduced. In contrast, chromosomes without $z$, namely, $w^{2 m}$ ct $m w f$ and $w^{2 m}$ ct $m w^{2} f$, show no enhancement.

Interestingly, the zeste-light allele of white $\left(w^{2}\right)$ (Becker 1960) is a derivative of zeste-mottled $\left(z w^{z m}\right)$ but is not affected by $m w . z w^{2 l}$ has more area of the male eye responding to $z$ than $w^{2 m}$. Also, it is genetically unstable (Judd 1963). The change from $w^{z m}$ to $w^{z 1}$ has eliminated the ability to respond to $m w$.

The interaction with $z$ is specific to the $w^{z m}$ allele since flies of the genotype $z w^{a} c t m w f / Y$ do not differ in the pattern of mottling from $w^{a} c t m w f / Y$ males. $z$ lightens $w^{a}$ (Becker 1960) but does not alter the pattern. $z$ does not permit wild-type $w$ to respond to $m w$ because a genotype of $z D p(1 ; 1) w^{+61 e 19} \mathrm{ct} m w$ fhows a nonmottled $z$ phenotype typical of duplications of the locus. Thus, $w^{2 m}$ and $z$ are both required for the phenotypic interaction with $m w$.

\section{Interaction of $\mathrm{mw}$ with other modifiers of $\mathrm{w}^{a}$}

The $m w$ was combined with other mutants that have been implicated in interacting with $w^{a}$. The three loci are $s u\left(w^{a}\right), s u(f)$, and Enhancer of $w^{a}\left[E\left(w^{a}\right)\right]$.

The $s u\left(w^{a}\right)$ locus specifically suppresses the apricot allele at $w$ and alters the spectrum of RNAs that are generated (Levis et al. 1984; Zachar et al. 1985). When a $y^{2}$ $s u\left(w^{a}\right)$ ct $m w^{2} f$ chromosome is produced, the eye color is darker than the same combination without the suppressor mutation but lighter than a $s u\left(w^{a}\right) w^{a}$ combination without $m w^{2}$. This indicates that the two mutants produce opposing effects but $m w^{2}$ is the stronger of the two.

The su(f) mutation acts to enhance the phenotype of $W^{a}$ and likewise has been shown to alter the pattern of RNAs produced from the apricot allele (Levis et al. 1984). The combination $w^{a} s u(f)$ has a much lighter shade of pigment than the normal $w^{a}$ constitution but is darker than $w^{a} m w^{2}$. When a $y^{2} w^{a} c t m w^{2} f s u(f)$ chromosome is produced, the level of pigment is reduced to below the level with either su(f) or $m w^{2}$. Thus, the two enhancers are additive.

The third locus tested in combination with $m w^{2}$, $E\left(w^{a}\right)$ is also specific to transposable element insertion alleles at white (J.A. Birchler and J.C. Hiebert, in prep.). When a $y^{2} w^{a} c t m w^{2} f$ male is crossed to females of $y w^{a}$; $E\left(w^{a}\right) / C y O$ constitution, the progeny can be divided into four classes: females heterozygous for $m w^{2}$ on the $\mathrm{X}$ 
chromosome and for $E\left(w^{a}\right)$ on the second chromosome, females heterozygous for $\mathrm{mw}^{2}$ and for the $\mathrm{CyO}$ balancer chromosome, males with $w^{a}$ on the $\mathrm{X}$ and heterozygous for $E\left(w^{a}\right)$ on the second chromosome, and males with $w^{a}$ on the $\mathrm{X}$ and heterozygous for $\mathrm{Cy} O$ on the second chromosome. From darkest to lightest, they are $C y$ male, $C y$ female, non- $C y$ male, and non- $C y$ female. This indicates that the $m w^{2}$ allele has a dominant effect and is cumulative in combination with the $E\left(w^{a}\right)$.

A reciprocal cross was performed that involved males of $y w^{a} / Y ; E\left(w^{a}\right) / C y 0$ genotype and females of $w^{a} m w^{2} /$ $w^{a} m w^{2}$. The hemizygous $m w^{2}$ sons have $E\left(w^{a}\right) /+$ or $\mathrm{CyO} /+$ second chromosome constitutions. The $w^{a}$ $m w^{2} / Y ; E\left(w^{a}\right) /+$ progeny have lighter eye color than their $w^{a} m w^{2} / Y ; C y O /+$ siblings.

\section{RNA analysis}

The $w^{a}$ mutation results from the insertion of a copia transposable element into the second intervening sequence of the $w$ locus (Gehring and Paro 1980; Bingham and Judd 1981). The mutant phenotype is believed to result from the termination of transcription from the $w$ promoter at sites within the copia element, primarily in the 3' LTR. The $s u(f)$ and $s u\left(w^{a}\right)$ mutations alter the ratio of termination products and the normal $2.6-\mathrm{kb}$ mRNAs (Levis et al. 1984; Zachar et al. 1985).

To test the effect of $m w$ on $w^{a}$, flies of $w^{a}+, w^{a} m w^{2}$ (produced from a segregating population), $w^{1118}$ (a deficiency for $w \mid$, and Canton $S$ were grown and separated according to sex. Previous phenotypic examination of $w^{a}$ $m w^{2}$ flies showed that the mutant effect of $m w^{2}$ occurs in all tissues where $w$ is expressed (eyes, Malpighian tubules, and testis sheath); therefore, whole fly RNA analysis is informative. RNA was isolated from each strain and analyzed on Northern gels. The blot was probed with an antisense RNA transcribed from a $T 7$ vector containing a fragment extending from the $\mathrm{XbaI}$ site immediately preceding the second exon to the Sall site near the end of the third exon. Thus, it spanned the second intervening sequence where copia was inserted and detected RNAs initiated at the transcription start site of the white locus, as well as any initiated with copia and terminating at the $3^{\prime}$ end of the $w$ transcription unit. In addition, a second blot containing the same samples was probed with labeled RNA transcribed from a vector containing a Sall fragment including a small portion of exon 3 and extending into exon 6 , which will only detect RNAs that contain sequences $3^{\prime}$ to the site of copia insertion. Finally, a third blot was probed with RNA transcribed from a vector, containing sequences extending from the BamHI to HindIII sites, that includes only the first exon, which will detect transcripts initiating at $w$ and terminating within copia.

A complex array of RNAs is generated by the $w^{a}$ allele (Levis et al. 1984; Pirrotta and Brockl 1984; Zachar et al. 1985). The comparison of the $w^{a}+$ and $w^{a} m w^{2}$ RNAs indicates that there is a drastic reduction in the level of 2.6-kb normal $w$ message, but the levels of other species of RNA are unaffected, with the exception of two species with homology to the $5^{\prime}$ probe but not the $3^{\prime}$ one and of a molecular weight slightly greater than the normal $w$ message. The homology of these two species of RNA to the first two exons of $w$ and their molecular weight suggest that they initiate at the $w$ promoter and terminate within copia, but do not contain all of the copia sequences. The results are shown in Figure 5.

The total RNA preparations from the population segregating for $w^{a}+$ and $w^{a} m w^{2}$ was also probed with a single-stranded RNA antisense to a copia segment extending from the HindIII to the ApaI restriction sites (Mount and Rubin 1985). There was no detectable quantitative or qualitative difference among the genotypes (Fig. 6).

As an additional test, equal quantities of total RNA were dotted onto nitrocellulose and probed with the copia sequence. After hybridization, washing, and autoradiography to check for gross background, the filters were counted by scintillation spectrometry. The mean ( \pm S.D. $)(n=10)$ of $\mathrm{cpm}$ in $w a+/ Y$ compared with $w^{a}$ $m w^{2} / Y$ males was $3012( \pm 449)$ and $3009( \pm 504)$, respectively. In females, $w^{a}+/ w^{a} m w^{2}$ versus $w^{a} m w^{2} / w^{a}$ $m w^{2}$ gave values of $2600( \pm 407)$ and $2334( \pm 350)$. Neither of these comparisons is significantly different in statistical tests at the $95 \%$ confidence level. These results confirmed the Northern analysis, indicating no quantitative modulation of total copia RNA levels by the $m w^{2}$ mutation.

An RNA species of low abundance is detected by the $3^{\prime} \mathrm{w}$ probe but not by the $5^{\prime}$ probe, which is of the appropriate molecular weight $(\sim 7.2 \mathrm{~kb})$ and $w$ homology to be a product initiated in the $5^{\prime}$ LTR of copia and terminated at the 3' terminus of $w$. In Northern blots of $w^{a}$, but not Canton $\mathrm{S}$ or other $\mathrm{w}^{+}$strains, probed with copia sequences, an RNA is detected of similar molecular weight. The quantity of this RNA is not modulated by $m w^{2}$.

\section{Conclusions}

An analysis of the $m w$ locus indicates that it is a specific modifier of $w$ alleles that are transposon-insertion mutants. Unlike other modifiers of insertion mutants at $w$, $m w$ is effective on alleles induced by a variety of transposons. The sites within the $w$ locus vary, but all are present within the structural portion of the gene.

Five of the six affected alleles result from a retrotransposon insertion: apricot, apricot-4, buff, spotted-55, and zeste-mottled. The sixth affected allele is honey, which is a deletion derivative of the Doc element insertion in $w^{1}$. Several other derivatives of $w^{1}$, namely $w^{e}$, $w^{e 2}, w^{c h}, w^{a p l}$, and $w^{I R 2}$ were also tested for interaction with $m w$, but none of these responded. The allele specificity of $m w$ suggests that it operates primarily, but not exclusively, on retrotransposon insertion mutants.

The mottling property of the original allele is unique. It is unaffected by genetic modifications that influence position effect variegation despite the gross phenotypic similarities. Analysis of the pattern of a tandem duplica- 


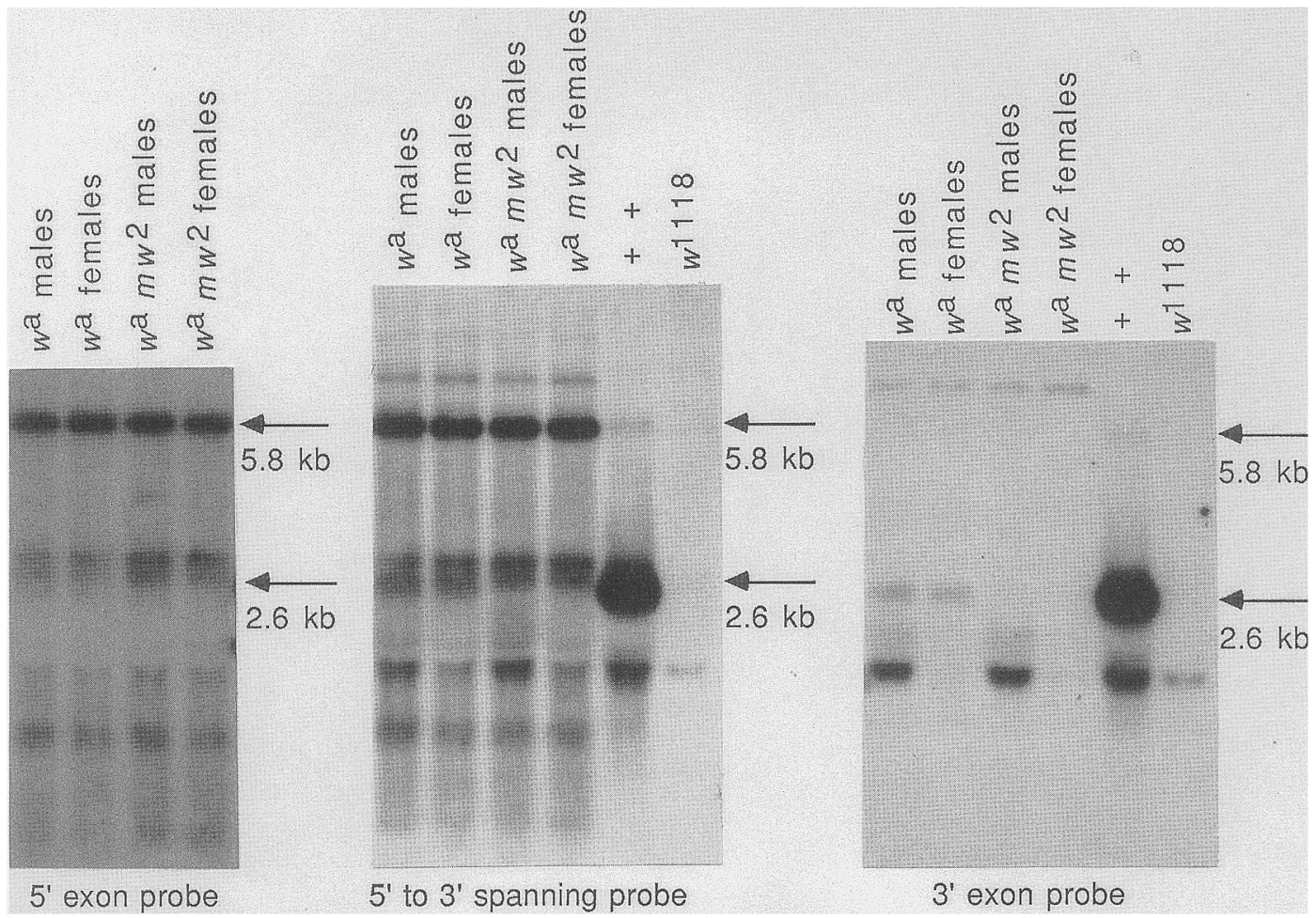

Figure 5. Northern analysis of $w^{a}$ RNA products in the presence of the $m w^{2}$ mutant. RNA was isolated from flies $(0-12 \mathrm{hr}$ old $)$ from a cross of $w^{a} m w^{2}$ males to $w^{a}+/ w^{a} m w^{2}$ females. Each blot was run separately and contains RNA from $w^{a}+m a l e s, w^{a}+/ w^{a} m w^{2}$ females, $w^{a} m w^{2}$ males, and $w^{a} m w^{2} / w^{a} m w^{2}$ females. Included in the center and right panels are lanes with RNA from wild type and from $w^{1118}$, a mutant deficient for the $5^{\prime}$ portion of $w$. (Left) The blot was probed with sequences homologous to the $5^{\prime}$ exon; (center) the blot was probed with sequences that span the site of copia insertion in $w_{\text {; }}($ right $)$ the blot was probed with sequences homologous to regions of $w 3^{\prime}$ to copia. The position of the $2.6-\mathrm{kb}$ normal $w$ message is marked in each panel, as well as the major $5.8-\mathrm{kb}$ RNA that initiates at $w$ and terminates at the $3^{\prime}$ of copia. In addition to these two RNAs, there is a pair with slightly greater molecular weight than the normal $w$ message, which have homology to the $5^{\prime}$ and spanning probes. An additional RNA species of lower molecular weight $(1.2 \mathrm{~kb})$ has homology to these two probes. Finally, a species of greater molecular weight than the 5.8-kb $3^{\prime}$ LTR termination product is detected with the spanning probe and the 3' exon. An additional RNA that has homology to all probes and is expressed at much greater levels in males than females is present in all cases, including wild type and the deletion strain $w^{1118}$; thus, it is unlikely to be a product of the $w$ locus. The effect of the $m w^{2}$ mutation is to eliminate the normal $2.6-\mathrm{kb}$ normal $w$ message /most easily seen in the $3^{\prime}$ exon panel) and to increase the two RNAs of slightly higher molecular weight, which have homology to the $5^{\prime}$ and spanning exon probes.

tion of $w^{a}$, a deficiency for $m w$, and the induction of a new allele that is not mottled all suggest that the mottling is due to events at the $m w$ locus and not $w^{a}$. It is postulated that each copy of $m w$ in a female independently inactivates at different points in development and that this inactivation is maintained in a cell lineage manner. The inactivation enhances transposon insertion mutants at $w$, thus producing the mosaic phenotype.

Possible mechanisms of the action of $m w$ on transposable element insertion alleles at $w$ are as follows. The absence of the $m w$ gene product would increase the degree of termination of $w$-initiated RNAs within the transposable element. The normal product of $m w$ might therefore be involved in permitting readthrough of the termination signals present in the respective transposons to give the low level of functional RNA and pigment characteristic of each allele. Second, $\mathrm{mw}^{+}$may be involved in RNA processing within the transposable ele- ment, and its elimination removes the processing pathway that leads to functional $w$ message. Finally, the insertion of copia has been shown to alter the developmental expression of $w$ itself (Zachar et al. 1985). The $m w$ product might be involved in regulating $w$ under the influence of the unique set of regulatory information.

The fact that the $m w^{2}$ mutation does not alter either total $w$ or total copia RNA levels, but reduces the level of the normal $2.6-\mathrm{kb}$ message suggests a role other than modulating the transcription rates of copia or $w$. The apparent shift of the normal $w$ message into one of the higher molecular weight forms present in $w^{a}$ suggests a role in alternative RNA processing.

While the available evidence suggests that $m w$ is involved in a processing function with the products of the $W^{a}$ allele, there is no evidence to suggest that this can be generalized to copia elements in other locations in the genome. In the absence of further data, it is important to 


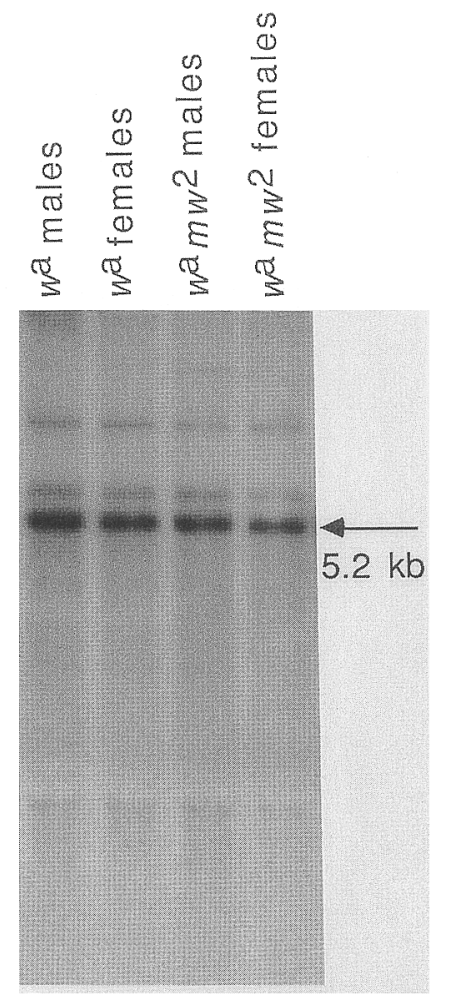

Figure 6. Northern analysis of copia RNA in the presence of the $m w^{2}$ mutant. The RNA samples described in Fig. 4 were separated on formaldehyde-agarose gels, transferred to nylon membrane, and probed with sequences homologous to copia. The samples (left to right) are $w^{a}+$ males, $w^{a}+/ w^{a} m w^{2}$ females, $w^{a} m w^{2}$ males, and $w^{a} m w^{2} / w^{a} m w^{2}$ females. The position of the major 5.2-kb RNA is marked.

note that sequences from $w$, as well as the respective transposable elements, may be required to produce the observed shift in RNA quantities.

In the case of $w^{2 m}$, the $z$ mutant must be effective upon $w$ for $m w$ to produce a recognizable response in males. Because the transposon in this case only has a mutant effect in the presence of $z$, it is possible that the transposon is only expressed then. It is potentially the case that the $m w$ requires the expression of the transposon to be effective. Alternatively, the phenotypic reduction caused by $z$ may allow the constant effect of $m w$ to be observed.

Parkhurst and Corces (1987) noted that different classes of retrotransposons have different developmental profiles of total RNA, as well as those of different molecular weight from a single class of element, suggesting certain evolutionary relationships and diversities among classes in terms of expression. Because $m w$ acts on $\mathrm{W}$ mutants caused by elements with diverse expression (namely, copia, B104, and 3S18), its involvement with retrotransposons appears to be antecedent to the diversity observed. Modifiers of transposon-induced mutants have generally been interpreted as representing normal cellular functions that are parasitized by the retrotransposons. It is also possible that given the wide phyloge- netic representation of retroelements, certain functions have been selected to have specificity for elements and loss of involvement in other cellular processes. Such a situation could be selected for by impairment of cellular functions by competition from retroelements. The extent of specificity must await further information about the role of various modifier genes.

\section{Methods \\ Drosophila culture}

Flies were grown on Instant Drosophila Medium /Carolina Biological Supply) at $25^{\circ} \mathrm{C}$.

\section{RNA extraction}

RNA was extracted from frozen flies by the method of Cox (1968). Homogenization was in $8 \mathrm{M}$ guanidine- $\mathrm{HCl}$ (UltraPure, Schwarz/Mann), $0.01 \mathrm{M}$ EDTA at a volume of $1 \mathrm{ml} / \mathrm{gm}$ of tissue, followed by ethanol precipitation with one-half volume. Four additional $4 \mathrm{M}$ guanidine, $0.01 \mathrm{M}$ EDTA/ethanol precipitations followed. The final pellet was extracted with diethylpyrocarbonate (DEPC)-treated water at a ratio of $1 \mathrm{ml} / \mathrm{gram}$ original tissue; a second water extraction was performed at $56^{\circ} \mathrm{C}$; the third at room temperature. After ethanol precipitation from the water extractions, the RNA was stored frozen in chelexed, DEPC-treated water at $-80^{\circ} \mathrm{C}$.

\section{Northern analysis}

RNA was separated on formaldehyde $-1.5 \%$ agarose gels by the method of Lehrach et al. (1977). Formaldehyde was present in the tank buffer at the same concentration as that in the gel. RNA was transferred to Nytran nylon membrane, UV crosslinked (Church and Gilbert 1984; Khandiian 1986), and baked at $80^{\circ} \mathrm{C}$ for $2 \mathrm{hr}$.

\section{Hybridization}

Filters of Northern blots were wetted in $5 \times$ SSC $11 \times$ $\mathrm{SSC}=0.15 \mathrm{M} \mathrm{NaCl} ; 0.015 \mathrm{M} \mathrm{Na}$ citratel, $0.1 \%$ SDS and prehy. bridized $\left(150 \mu \mathrm{l} / \mathrm{cm}^{2}\right)$ in a solution of $50 \%$ formamide, deionized with AG 501-X8 (Bio-Rad) resin, $5 \times$ SSC, $10 \mathrm{~mm}$ polyvinylpyrrolidine, $1 \%$ bovine serum albumin, $0.5 \%$ SDS, and 0.2 $\mathrm{mg} / \mathrm{ml}$ calf thymus DNA (Sigma) for $4 \mathrm{hr}$ at $60^{\circ} \mathrm{C}$. Hybridization was started by the addition of ${ }^{32} \mathrm{P}$-labeled probe at $2 \times 10^{6}$ $\mathrm{cpm} / \mathrm{ml}$ of solution and was conducted for $16 \mathrm{hr}$ followed by four washes consisting of $0.1 \times \mathrm{SSC}, 5 \mathrm{mM} \mathrm{NaH} \mathrm{HPO}_{4}, 0.015 \%$ pyrophosphate, $0.2 \% \operatorname{SDS}(\mathrm{pH} 7.0)$, each for $30 \mathrm{~min}$ at $75^{\circ} \mathrm{C}$. The filters were then washed at room temperature twice for 30 $\mathrm{min}$ in $3 \mathrm{mM}$ Tris- $\mathrm{HCl}$ (pH 9.0). Filters were dried and subjected to autoradiography with Kodak XRP-1 film overnight at $70^{\circ} \mathrm{C}$.

\section{Dot blots}

Pieces of nitrocellulose $(8 \times 20 \mathrm{~cm})$ were marked in 2-cm squares with a lead pencil. The sheets were wetted in water and then soaked in $20 \times \operatorname{SSC}\{1 \times=0.15 \mathrm{M} \mathrm{NaCl}, 0.015 \mathrm{M} \mathrm{Na}$ citrate) for $4 \mathrm{hr}$ prior to RNA application (Thomas 1980). The filters were then blotted to dampness on Whatman No. 3MM paper. The RNA $(4 \mu \mathrm{g} / \mathrm{dot})$ was applied to the center of the squares in 4-ml aliquots in 10 replicas each for $w^{a}+$ males, $w^{a}$ $m w^{2}$ males, $w^{a}+/ w^{a} m w^{2}$ females, and $w^{a} m w^{2} / w^{a} m w^{2}$ females. The filters were placed between two sheets of Whatman 
No. $3 \mathrm{MM}$ paper and baked under vacuum for $2 \mathrm{hr}$ at $80^{\circ} \mathrm{C}$. After hybridization and washing, the filters were subjected to autoradiography to check for gross background, cut into individual squares, dried under a heat lamp, and counted in $5 \mathrm{ml}$ of toluene plus $4 \%$ Scintiprep (Fisher) in a Beckman LS 1801 scintillation counter.

\section{DNA isolation}

DNA from $w^{a}+, w^{a} m w^{2}$, and Canton $S$ was prepared by the method of Bingham et al. (1981).

\section{Oligolabeling}

Drosophila $w$ locus DNA was labeled according to manufacturer's (Pharmacia) specifications and the procedure of Feinberg and Vogelstein (1983).

\section{Probe isolation}

A fragment of Drosophila DNA, extending from the $X b a I$ to Sall restriction sites surrounding coordinate 0 of Levis et al (1982), was digested from the plasmid. The fragment and vector were separated in a $1 \%$ agarose gel, and the fragment was electroeluted and purified on an Elutip column (Schleicher and Schuell), followed by ethanol precipitation $(0.33 \mathrm{M} \mathrm{Na}$ acetate and two volumes of ethanol).

\section{Hybridization}

Filter hybridization of Southern blots was conducted at $65^{\circ} \mathrm{C}$, according to Church and Gilbert (1984), with the following modification. The hybridization solution was $50 \%$ (wt/vol) polyethylene glycol.

\section{Probe preparation}

Single-stranded RNA probes were generated from a T7/SP6 vector (IBI 76, International Biotechnology, Inc.) (Green et al. 1983 into which had been subcloned fragments of the white locus, extending from the BamHI to the HindIII site surrounding the first exon (designated pIBI $11.5 \mathrm{HB}$ ), from the $\mathrm{XbaI}$ to SalI sites surrounding the second and third exons (pIBI 12.5 $\mathrm{XS|}$, and a SalI fragment including a small portion of exon 3 and extending into exon 6 (pIBI $12.3 \mathrm{SS}$ ). The reaction mix consisted of the following: $40 \mathrm{~mm}$ Tris- $\mathrm{HCl}(\mathrm{pH} 7.5), 6 \mathrm{mM} \mathrm{MgCl}, 2 \mathrm{mM}$ spermidine, $0.5 \mathrm{~mm}$ ATP, $0.5 \mathrm{mM}$ CTP, $0.5 \mathrm{~mm} \mathrm{GTP}, \sim 150 \mu \mathrm{Ci}$ [32P]UTP (3000 Ci/mmole) (New England Nuclear), 40 units RNasin (Promega Biotec), 15 units T7 Polymerase (New England Biolabs), and $0.5 \mu \mathrm{g}$ linearized plasmid in a total volume of $20 \mu \mathrm{l}$. The reaction was incubated at $37^{\circ} \mathrm{C}$ for $1 \mathrm{hr}$, at which point the volume was adjusted to $50 \mu \mathrm{l}$ with $0.01 \mathrm{M}$ Tris-Cl, $0.01 \mathrm{M}$ EDTA (pH 8.0). One microliter was removed and diluted to $50 \mu \mathrm{l}$ in water. Twenty microliters of the diluted sample was spotted onto Whatman No. $12.3-\mathrm{cm}$ disks. One was dried directly and the second washed twice in $250 \mathrm{ml}$ of $5 \%$ trichloroacetic acid plus $1 \%$ sodium pyrophosphate, once in $250 \mathrm{ml}$ of absolute ethanol and finally in $250 \mathrm{ml}$ of anhydrous ether. The washed filter was dried under a heat lamp, and both were counted in a Beckman LS 1801 scintillation counter to determine the percent of incorporation of label into RNA.

The completed reaction mixture was applied to a spin column of Sephadex G-50. The RNA recovered from the column was precipitated by addition of $1 \mu \mathrm{g}$ of Escherichia coli transfer RNA per $50 \mu \mathrm{l}$ recovered from the column, one-tenth volume $2 \mathrm{M}$ sodium acetate, and two volumes of absolute eth- anol. After centrifugation and resuspension in $100 \mu \mathrm{l}$ of sterile DEPC-treated $\mathrm{H}_{2} \mathrm{O}$, the appropriate volumes were added to the hybridization bags.

\section{In situ hybridization}

In situ hybridization was conducted as described by LangerSafer et al. (1982), using a P-element probe biotinylated with biotin-16-dUTP (ENZO) and detected by reaction with a streptavidin-biotinylated peroxidase complex (ENZO) and staining with diaminobenzidine (ENZO), $0.03 \% \mathrm{H}_{2} \mathrm{O}_{2}$ at $37^{\circ} \mathrm{C}$ for 20 min.

\section{Acknowledgments}

Research was supported by a grant from the National Science Foundation. Discussions with Danielle Thierry-Mieg, Bob Levis, Steve Mount, Richard Linsk, and Mary Alleman were helpful. Plasmids of white and copia DNA were kindly supplied by Bob Levis. We thank the following individuals for fly stocks: Caltech, Bowling Green, Indiana, Umea stock centers, Danielle Thierry-Mieg, Bob Levis, Steve Mount, Paul Bingham, and Mel Green. We are also grateful to Ellie Valminuto and Karen McCree-Diaz for their help in preparing the manuscript.

\section{References}

Becker, H.J. 1960. Variegation in the zeste eye color alleles and its bearing on gene action during the development of the eye of Drosophila melanogaster. Genetics 45: 519-534.

Bingham, P.M. and C.H. Chapman. 1986. Evidence that whiteblood is a novel type of temperature-sensitive mutation resulting from temperature-dependent effects of a transposon insertion on formation of white transcripts. EMBO $I$. 5: 3343-3351.

Bingham, P.M. and B.H. Judd. 1981. A copy of the copia transposable element is very tightly linked to the $w^{a}$ allele at the white locus of D. melanogaster. Cell 25: 705-711.

Bingham, P.M., R. Levis, and G.M. Rubin. 1981. Cloning of DNA sequences from the white locus of $D$. melanogaster by a novel and general method. Cell 25: 693-704.

Bryan, G.J., J.W. Jacobsen, and D.L. Hartl. 1987. Heritable somatic excision of a Drosophila-transposon. Science 235: 1636-1638

Carbonare, B.D. and W.J. Gehring. 1985. Excision of copia element in a revertant of the white-apricot mutation of Drosophila melanogaster leaves behind one long-terminal repeat. Mol. Gen. Genet. 199: 1-6.

Church, G.M. and W. Gilbert. 1984. Genomic sequencing. Proc. Natl. Acad. Sci. 81: 1991-1995.

Collins, M. and G.M. Rubin. 1982. Structure of the Drosophila mutable allele, white-crimson, and its white-ivory and wild-type derivatives. Cell 30: 71-79.

Cox, R.A. 1968. The use of guanidium chloride in the isolation of nucleic acids. Methods Enzymol. 12: 120-129.

Davison, D., C.H. Chapman, C. Wedeen, and P.M. Bingham. 1985. Genetic and physical studies of a portion of the white locus participating in transcriptional regulation and in synapsis-dependent interactions in Drosophila adult tissues. Genetics 110: 494-497.

Feinberg, A.P. and B. Vogelstein. 1983. A technique for radiolabeling DNA restriction endonuclease fragments to high specific activity. Anal. Biochem. 132: 6-13.

Fincham, J.R.S. and G.R.K. Sastry. 1974. Controlling elements in maize. Annu. Rev. Genet. 8: 15-50. 
Fujisawa, J.I., M. Seiki, T. Kiyokawa, and M. Yoshida. 1985. Functional activation of the long terminal repeat of human T-cell leukemia virus type I by a trans-acting factor. Proc. Natl. Acad. Sci. 82: 2277-2281.

Gehring, W.J. and R. Paro. 1980. Isolation of a hybrid plasmid with homologous sequences to a transposing element of Drosophila. Cell 19: 857-904.

Green, M.M. 1959a. Non-homologous pairing and crossing over in Drosophila melanogaster. Genetics 44: 1243-1256.

. 1959b. Spatial and functional properties of pseudo alleles at the white locus in Drosophila melanogaster. Heredity 13: $303-315$.

Green, M.R., T. Maniatis, and D.A. Melton. 1983. Human betaglobin pre-mRNA synthesized in vitro is accurately spliced in Xenopus oocyte nuclei. Cell 32: 681-694.

Gsell, R. 1971. Untersuchungen zer Stabilitat einer yellow Postionseffeckt Variegation in Imanginalscheiben-Kulturen von Drosophila melanogaster. Mol. Gen. Genet. 110: 218-237.

Hazelrigg, T. 1987. The Drosophila white gene: A molecular update. Trends Genet. 3: 43-47.

Ising, G. 1964. A recessive lethal in chromosome 2, which in a single dose has an effect on the eye color of white animals. Dros. Inf. Serv. 39: 74.

Judd, B.H. 1963. The genetic fine structure of the mutants $z^{m}$ and $z^{1}$ in Drosophila melanogaster. Genet. Today 1: 3-4.

Karess, R.E. and G.M. Rubin. 1982. A small tandem duplication is responsible for the unstable white-ivory mutation in Drosophila. Cell 30: 63-69.

Khandjian, E.W. 1986. UV crosslinking of RNA to nylon membrane enhances hybridization signals. Mol. Biol. Rep. 11: $107-115$.

Langer-Safer, P.R., M. Levine, and D.C. Ward. 1982. Immunological method for mapping genes on Drosophila polytene chromosomes. Proc. Natl. Acad. Sci. 79: 4381-4385.

Lehrach, H., D. Diamond, J.M. Wozney, and J. Boedtker. 1977. RNA molecular weight determinations by gel electrophoresis under denaturing conditions, a critical reexamination. Biochemistry 16: 4743-4751.

Levis, R., P.M. Bingham, and G.M. Rubin. 1982. Physical map of the white locus of Drosophila melanogaster. Proc. Natl. Acad. Sci. 79: 564-568.

Levis, R., T. Hazelrigg, and G.M. Rubin. 1985. Separable cisacting control elements for expression of the white gene of Drosophila. EMBO I. 4: 2489-3499.

Levis, R., K. O'Hare, and G.M. Rubin. 1984. Effects of transposable element insertions on RNA by the white gene of Drosophila. EMBO I. 4: 2489-3499.

Lindsley, D.L. and E.H. Grell. 1968. Genetic variations of Drosophila melanogaster. Carnegie Inst. Washington Publ. 627.

Mount, S.M. and G.M. Rubin. 1985. Complete nucleotide sequence of the Drosophila transposable element copia: Homology between copia and retro-viral proteins. Mol. Cell. Biol. 7: 1630-1638.

Mount. S.M., M.M. Green, and G.M. Rubin. 1988. Partial revertants of the transposable element-associated suppressible allele white-apricot in Drosophila melanogaster: Structure and responsiveness to genetic modifiers. Genetics 118: $221-234$.

Muller, H.J. 1946. Two mutants of mosaic expression not caused by gross rearrangement of heterochromatin. Dros. Inf. Serv. 20: 88-89.

O'Hare, K., R. Levis, and G.M. Rubin. 1983. Transcription of the white locus in Drosophila melanogaster. Proc. Natl. Acad. Sci. 80: 6917-6921.

O'Hare, K., C. Murphy, R. Levis, and G.M. Rubin. 1984. DNA sequence of the white locus of Drosophila melanogaster. I.
Mol. Biol. 180: 437-455.

Oster, I.I. 1957. Two unusual cases of white-variegation. Dros. Inf. Serv. 31: 150.

Parkhurst, S.M. and V.G. Corces. 1987. Developmental expression of Drosophila melanogaster retrovinus-like transposable elements. EMBO J. 6: 419-424.

Pirrotta, V. and C. Brockl. 1984. Transcription of the Drosophila white locus and some of its mutants. EMBO I. 3: 563568.

Rubin, G.M., M.G. Kidwell, and P.M. Bingham. 1982. The molecular basis of hybrid dysgenesis: The nature of induced mutations. Cell 29: 987-994.

Sang, H.M., A. Pelisson, A. Bucheton, and D.J. Finnegan. 1984. Molecular lesions associated with white gene mutations induced by I-R hybrid dysgenesis in Drosophila melanogaster. EMBO J. 3: 3079-3085.

Spofford, J.B. 1976. Position-effect variegation in Drosophila. In The genetics and biology of Drosophila lc (ed. M. Ashburner and Novitski), pp. 955-1018. Academic Press, London.

Thomas, P.S. 1980. Hybridization of denatured RNA and small DNA fragments transferred to nitrocellulose. Proc. Natl. Acad. Sci. 77: 5201-5205.

Zachar, Z. and P.M. Bingham. 1982. Regulation of white locus expression: The structure of mutant alleles at the white locus of Drosophila melanogaster. Cell 30: 529-541.

Zachar, Z., D. Davison, D. Garza, and P.M. Bingham. 1985. A detailed developmental and structural study of the transcriptional effects of insertion of copia transposon into the white locus of Drosophila melanogaster. Genetics 111: $495-515$. 


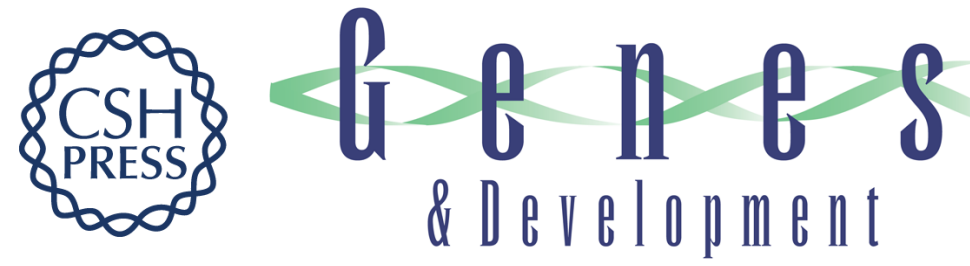

\section{Interaction of the mottler of white with transposable element alleles at the white locus in Drosophila melanogaster.}

J A Birchler, J C Hiebert and L Rabinow

Genes Dev. 1989, 3:

Access the most recent version at doi:10.1101/gad.3.1.73

References This article cites 41 articles, 11 of which can be accessed free at:

http://genesdev.cshlp.org/content/3/1/73.full.html\#ref-list-1

License

Email Alerting Receive free email alerts when new articles cite this article - sign up in the box at the top Service right corner of the article or click here.

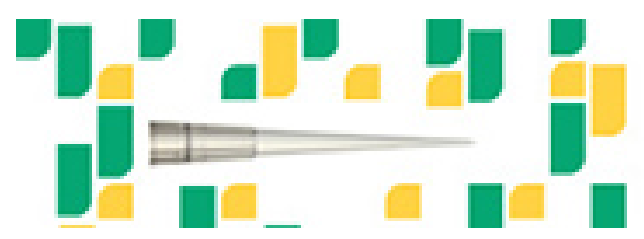

Focused on your science. 